\title{
Pengaruh Kebijakan Dividen, Kebijakan Utang, Profitabilitas, Kepemilikan Manajerial, dan Komite Audit terhadap Nilai Perusahaan
}

\author{
Siti Rohmah", ${ }^{1, *}$ Ahalik $^{2}$ \\ 1,*Akuntansi, Fakultas Bisnis,Kalbis Institute \\ Jalan Pulomas Selatan Kav. 22, Jakarta 13210. e-mail: Sitirahmah_15@yahoo.com \\ 1,* Akuntansi, Fakultas Bisnis,Kalbis Institute \\ Jalan Pulomas Selatan Kav. 22, Jakarta 13210. e-mail: Ahalik@kalbis.ac.id \\ *Korespondensi: email: Sitirahmah_15@yahoo.com
}

Diterima: 09 Maret 2020; Review: 20 April 2020; Disetujui: 01 Mei 2020

Cara Sitasi: Rohmah S, Ahalik. 2020. Pengaruh Kebijakan Dividen, Kebijakan Utang, Profitabilitas, Kepemilikan Manajerial, dan Komite Audit terhadap Nilai Perusahaan. Jurnal Online Insan Akuntan. Vol. 5 (1): 41-56.

\begin{abstract}
Abstrak:Penelitian ini dilakukan dengan tujuan untuk mengetahui pengaruh kebijakan dividen, kebijakan utang, profitabilitas, kepemilikan manajerial, dan komite audit terhadap nilai perusahaan. Teknik pemilihan sampel penelitian ini menggunakan purposive sampling. Sampel dalam penelitian ini adalah sebanyak 75 perusahaan manufaktur yang terdaftar di BEI periode 2013-2017. Data penelitian ini menggunakan data dari laporan keuangan dari setiap perusahaan sampel. Analisis data penelitian ini menggunakan analisis regresi berganda dengan pemakaian SPSS 24. Nilai perusahaan dalam penelitian ini diukur dengan rasio Tobin's Q. Hasil penelitian ini menunjukkan kebijakan dividen, kebijakan utang, profitabilitas, kepemilikan manajerial dan komite audit secara bersama-sama berpengaruh terhadap nilai perusahaan. Variabel kebijakan dividen (DPR), kebijakan utang (DER), kepemilikan manajerial (KM) dan komite audit (KA) tidak berpengaruh terhadap nilai perusahaan, sedangkan profitabilitas (ROE) berpengaruh positif signifikan terhadap nilai perusahaan.
\end{abstract}

Kata Kunci:kebijakan dividen, kebijakan utang, nilai perusahaan, profitabilitas.

\begin{abstract}
This research was conducted with the aim to determine the effect of dividend policy, debt policy, profitability, managerial ownership, and audit committee on firm value. The technique of selecting this research sample using purposive sampling. The sample in this study were 75 manufacturing companies listed on the Stock Exchange in the period 2013-2017. This research data uses data from financial statements from each sample company. The data analysis of this study uses multiple regression analysis with the use of SPSS 24. The company value in this study is measured by Tobin's $Q$ ratio. The results of this study indicate dividend policy, debt policy, profitability, managerial ownership and audit committee jointly influence the firm value. The variable dividend policy (DPR), debt policy (DER), managerial ownership (KM) and audit committee (KA) did not affect the value of the company, while profitability (ROE) had a significant positive effect on firm value.
\end{abstract}

Keywords:dividend policy, debt policy, firm value, profitability

\section{Pendahuluan}

Pada awal tahun 2019, Perusahaan transportasi Grab mengumumkan menjadi startup dengan status Decacorn pertama di Asia Tenggara. Hal ini berkaitan dengan pendanaan yang baru saja di dapat Grab pada akhir tahun 2018 sebanyak US\$ 3 miliar. Pendanaan tersebut menjadikan total valuasi Grab sebanyak lebih dari US\$ 11 miliar atau Rp 158,6 triliun. Dengan total valuasi lebih dari US\$ 11 miliar, menjadikan Grab sejajar dengan 
perusahaan lain yang telah terlebih dahulu menyandang status Decacorn seperti Uber dengan total valuasi sebesar US\$ 72 miliar, Airbnb dengan total valuasi sebesar US\$29, 3 miliar, dan Pinterest dengan valuasi sebesar US\$ 12,3 miliar. Perusahaan Decacorn adalah perusahaan dengan total valuasi diatas US\$ 10 miliar (CNN Indonesia, 2019). Nilai valuasi adalah nilai perusahaan untuk suatu perusahaan startup. Nilai valuasi bisa dijadikan acuan dalam mengukur potensi suatu perusahaan startup. Berbeda dengan nilai perusaaan pada umumnya, tidak ada perhitungan yang pasti dalam nilai valuasi startup. Nilai perusahaan adalah nilai jual perusahaan yang sedang beroperasi (Sartono, 2010:487).

Nilai perusahaan dapat ditingkatkan dengan adanya Good Corporate Governance (GCG). Dalam penelitian ini variabel GCG akan di wakilkan dengan kepemilikan manajerial dan komite audit. Kepemilikan manajerial adalah kepemilikan saham atas pihak manajemen (direktur dan komisaris) dari total saham yang telah beredar. Dengan adanya kepemilikan manajerial, pihak manajemen akan semakin memiliki rasa tanggung jawab terhadap perusahaan karena pihak manajemen tidak hanya bertindak sebagai agen namun juga sebagai pemegang saham. Hal ini dibuktikan pada penelitian sebelumnya yang dilakukan oleh Puspaningrum (2017) yang menghasilkan kepemilikan manajerial berpengaruh positif terhadap nilai perusahaan, berarti semakin banyak kepemilikan manajerial akan semakin meningkatkan nilai perusahaan.

Variabel GCG lainnya dalam penelitian ini adalah komite audit. Tugas komite audit adalah melakukan fungsi pengawasan dalam penyajian laporan maupun dalam kepatuhan regulasi perusahaan guna membantu dewan komisaris. Semakin banyak jumlah komite audit maka akan semakin baik pengawasan terhadap penyajian laporan sehingga dapat menghindari manipulasi dalam pelaporan. Dengan menghindari manipulasi pelaporan keuangan maka akan semakin meningkatkan kepercayaan investor terhadap perusahaan sehingga dapat meningkatkan nilai perusahaan. Penelitian yang dilakukan oleh Syafitri, Nuzula, \& Nurlaily (2018) menunjukkan bahwa komite audit berpengaruh terhadap nilai perusahaan.

Nilai perusahaan juga dapat dilihat dari seberapa besar kemampuan perusahaan dalam membayar dividen kepada para investornya. Hal ini karena dividen merupakan fokus bagi para calon investor, dengan semakin besar pembagian dividen maka akan menarik minat investor untuk berinvestasi sehingga harga saham dan nilai perusahaan akan meningkat. Pada penelitian sebelumnya yang dilakukan oleh Ayem \& Nugroho 
(2016) didapatkan hasil bahwa kebijakan dividen berpengaruh positif dan signifikan terhadap nilai perusahaan.

Faktor lain yang dapat mempengaruhi nilai perusahaan adalah kebijakan utang. Dalam penggunaan dana, harus diperhatikan besar manfaat yang diberikan dan besar biaya yang timbul dari penggunaan dana tersebut. Para investor akan melihat seberapa mampu perusahaan mengelola pendanaan yang di dapat apakah akan menghasilkan keuntungan yang lebih besar dibandingkan dengan biaya yang timbul atas pendanaan tersebut. Pada penelitian yang dilakukan oleh Kartini \& Apriwenni (2017) menunjukan bahwa kebijakan utang berpengaruh terhadap nilai perusahaan

Selain kebijakan dividen dan kebijakan hutang, faktor lain yang dapat mempengaruhi nilai perusahaan adalah profitabilitas. Profitabilitas adalah kemampuan perusahaan dalam menghasilkan laba. Kinerja perusahaan yang baik dapat meningkatkan nilai perusahaan. . Hal ini sejalan dengan penelitian yang dilakukan oleh Dhani \& Utama (2017) yang menyatakan bahwa profitabilitas berpengaruh terhadap nilai perusahaan.

Pemilihan perusahaan manufaktur pada penelitian ini karena saat ini banyak investor yang mengembangkan sektor industri manufaktur. Selain itu Indonesia saat ini telah mencapai nilai Manufacturing Value Added (MVA) sebesar 4,84 \%. Posisi ini merupakan posisi tertinggi diantara negara ASEAN karena rata-rata negara ASEAN MVA sekitar 4,5 $\%$ (Republika, 2018).

Tujuan dalam penelitian ini adalah sebagai berikut :

1. Untuk mengetahui dan menganalisis apakah kebijakan dividen berpengaruh terhadap nilai perusahaan.

2. Untuk mengetahui dan menganalisis apakah kebijakan utang berpengaruh terhadap nilai perusahaan.

3. Untuk mengetahui dan menganalisis apakah profitabilitas berpengaruh terhadap nilai perusahaan.

4. Untuk mengetahui dan menganalisis apakah kepemilikan manajerial berpengaruh terhadap nilai perusahaan.

5. Untuk mengetahui dan menganalisis apakah komite audit berpengaruh terhadap nilai perusahaan.

6. Untuk mengetahui dan menganalisis apakah kebijakan dividen, kebijakan utang, profitabilitas, kepemilikan manajerial, dan komite audit berpengaruh bersama-sama terhadap nilai perusahaan. 
Gambar 1. Kerangka Konseptual

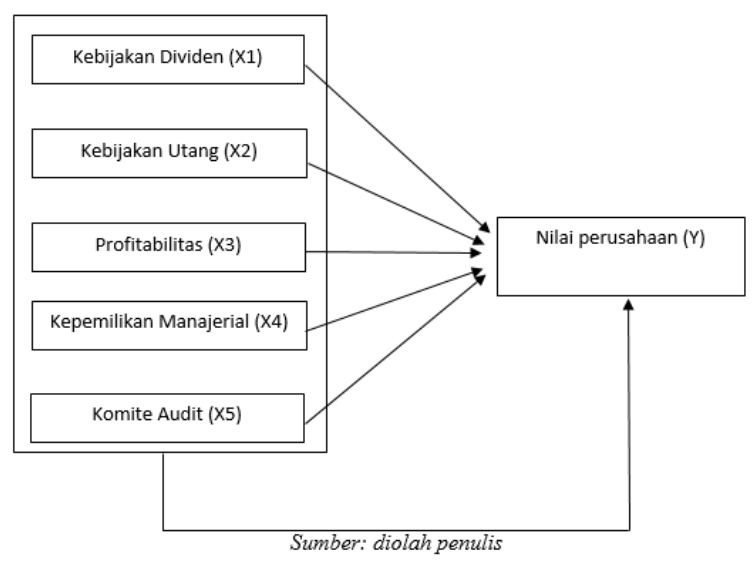

Berdasarkan gambar 1, maka diperoleh hipotesis sebagai berikut:

H1 : Kebijakan dividen berpengaruh terhadap nilai perusahaan

Laba pada dasarnya dapat di bagikan sebagai dividen atau menjadi laba ditahan untuk investasi perusahaan dikemudian hari. Pembagian dividen yang cukup besar dapat mencerminkan kinerja perusahaan yang baik. Tentunya kinerja perusahaan yang baik dapat menarik minat investor sehingga dapat menaikkan harga saham yang kemudian berimbas dengan peningkatan nilai perusahaan.

H2 : Kebijakan utang berpengaruh terhadap nilai perusahaan

Menurut Kartini \& Apriwenni (2017) tingkat keuntungan yang dihasilkan dari utang dapat meningkatkan nilai perusahaan. Kebijakan utang dapat meningkat nilai perusahaan hanya pada sampai titik tertentu. Penggunaan utang dapat memberikan keuntungan yang lebih dibanding dengan biaya yang harus dikeluarkan untuk utang tersebut.

H3 : Profitabilitas berpengaruh terhadap nilai perusahaan

Profitabilitas merupakan kemampuan perusahaan dalam menghasilkan laba. Laba adalah cerminan dari kinerja manajemen yang baik, oleh sebab itu para pemegang saham sangat mempertimbangan laba perusahaan sebelum berinvestasi. Laba yang besar dapat meningkatkan kesejahteraan para pemegang saham sehingga menarik minat para investor untuk membeli saham tersebut. Dengan tingginya permintaan saham maka dapat meningkatkan nilai perusahaan.

H4 : Kepemilikan manajerial terhadap nilai perusahaan

Semakin banyak saham yang dimiliki pihak manajemen maka akan semakin meningkatkan tanggung jawab manajemen terhadap perusahaan. Hal ini disebabkan karena pihak manajemen telah memiliki kepentingan yang sama dengan para pemegang 
saham lainnya. Dengan optimalnya kinerja pihak manajemen maka dapat meningkatkan nilai perusahaan.

H5 : Komite audit berpengaruh terhadap nilai perusahaan

Menurut Syafitri, Nuzula, \& Nurlaily (2018) semakin banyak jumlah komite audit maka akan semakin meningkatkan nilai perusahaan. Komite audit dibentuk oleh dewan direksi untuk membantu pengawasan laporan keuangan dan pelaksanaan peraturan lainnya. Laporan keuangan dengan pengawasan yang ketat dapat menghindari manipulasi isi laporan keuangan tersebut. Dengan rendahnya tingkat manipulasi laporan keuangan maka akan semakin meyakinkan investor untuk membeli saham perusahaan.

\section{Metode Penelitian}

\section{A. Kajian Teori dan Perumusan Hipotesis}

Teori Keagenan

Menurut Jensen and Meckling (1976) pihak manajemen sebagai agen ditunjuk oleh pemilik perusahaan sebagai prinsipal untuk menjalankan bisnis atas nama pemilik perusahaan. Dengan hal ini pihak manajemen harus berusaha untuk memaksimalkan kesejahteraan pemilik perusahaan sebagai bentuk tanggung jawab dari menjalankan bisnis. Namun pada kenyataannya sering terjadi perbedaaan kepentingan antara manajer dengan pemilik perusahaan.

Perbedaan kepentingan antara pihak manajemen dengan pemilik perusahaan akan menimbulkan konflik kepentingan. Motivasi pemilik perusahaan (princle) melakukan hubungan kontrak dengan pihak manajemen (agent) adalah untuk kesejahteraan dirinya yang di dapat dari laba yang akan dihasilkan perusahaan, sedangkan motivasi pihak manajemen adalah untuk mendapatkan pinjaman ataupun investasi dari pemegang saham baru (Kartini \& Apriwenni, 2017:50).

Teori Signal

Manajer akan memberikan sinyal mengenai kondisi perusahaan melalui laporan keuangan yang diterbitkan. Dari laporan keuangan, investor akan mendapat sinyal mengenai kondisi keuangan perusahaan, apakah perusahaan dalam kondisi keuangan yang baik untuk dimasa mendatang atau bahkan sebaliknya menjadi sinyal negatif untuk investor berinvestasi (Godfrey, 2010:375-376).

Sinyal baik dari perusahaan dapat menunjukkan kinerja perusahaan yang baik, sehingga dapat dijadikaan acuan oleh investor sebelum berinvestasi. Investor akan lebih tertarik dengan perusahaan yang semakin banyak memberikan informasi. Namun semakin banyak perusahaan 
yang memberikan sinyal dari laporan keuangan maka semakin diragukan kredibilitasnya (Godrey. 2010:376).

Salah satu sinyal yang harus diperhatikan sinyal mengenai pembagian dividen. Dengan memperlancar pembagian dividen maka ketertarikan investor akan semakin meningkat sehingga dapat meningkatkan laba dikemudian hari. Peningkatan laba dikemudian hari akan berdampak pada pembagian dividen yang tinggi dikemudian hari (Godrey, 2010:376).

Nilai Perusahaan

Nilai perusahaan bisa dilihat berdasarkan keinginan investor untuk memiliki saham perusahaan. Semakin banyak investor yang menginginkan saham perusahaan akan semakin meningkatkan nilai perusahaan (Tambunan, Saifi, \& Hidayat, 2017:52).

Investor yakin jika dengan semakin tingginya nilai perusahaan maka semakin mencerminkan kinerja perusahaan yang baik (Assyaari, Pratomo, \& Yudowati, 2018:630). Pada penelitian ini, penulis menggunakan rasio Tobin's Q sebagai pengukuran variabel nilai perusahaaan. Rasio Tobin's Q dipilih karena dalam perhitungannya, kewajiban ikut diperhitungkan sehingga dapat mencerminkan nilai perusahaan yang sesungguhnya.

Kebijakan Dividen

Kebijakan dividen adalah keputusan apakah perusahaaan akan membagikan laba perusahaan kepada pemegang saham dalam bentuk dividen atau mempertahankan laba untuk pembiayaan investasi dikemudian hari (Mulyawan, 2015:243). Menurut Kartini \& Apriwenni (2017:51) kebijakan dividen memiliki tiga teori dasar yaitu:

Dividen Tidak Relevan

Kemakmuran investor tidak dipengaruhi oleh pembayaran dividen dalam kondisi keputusan investasi.

\section{Bird-in-the-hand Theory}

Investor lebih menyukai dividen dibanding dengan capital gains karena tingkat ketidakpastian dividen lebih rendah

Tax Preference Theory

Tarif pajak untuk capital gains lebih rendah dibandingkan dengan dividen. Oleh karena itu investor lebih menyukai capital gains dibanding dengan pembayaran dividen.

Kebijakan Utang

Kebijakan utang adalah keputusan bagaimana perusahaan mendapatkan pendanaan untuk kegiatan perusahaan. Menurut Kartini \& Apriwenni (2017:51) terdapat dua teori kebijakan utang sebagai berikut: 
Trade Off Theory

Peningkatan nilai perusahaan dapat disebabkan karena penggunaan utang, namun penggunaan utang hanya pada sampai titik tertentu. Setelah melewati titik tersebut penggunaan utang justru dapat menurunkan nilai perusahaan.

Pecking Order Theory

Pendanaan yang berasal dari penggunaan utang lebih banyak dipilih dibanding dengan penerbitan saham baru.

Profitabilitas

Profitabilitas adalah kemampuan suatu perusahaan untuk memperoleh keuntungan dalam menjalankan bisnisnya (Sunyoto, 2013:113). Menurut Sunyoto (2013: 114) rasio profitabilitas dibagi menjadi 3 macam, yaitu:

Rasio Profit Margin

Diperoleh dari persentase laba bersih setelah pajak dibagi dengan penjualan bersih

Rasio Pengembalian Modal Sendiri

Diperoleh dari persentase laba bersih setelah pajak dibagi dengan modal sendiri atau aktiva bersih

RasioPengembalian Aset

Diperoleh dari persentase laba bersih setelah pajak dibagi dengan total aktiva.

Kepemilikan Manajerial

Kepemilikan manajerial adalah kepemilikan saham atas pihak manajemen (direktur dan komisaris) dari total saham yang telah beredar. Pihak manajer akan senantiasa turut serta dalam meningkatkan nilai perusahaan dengan lebih bertanggung jawab dalam pengambilan keputusan (Puspaningrum, 2017:3). Kepemilikan manajer akan menyamakan tujuan antara pemegang saham dengan pihak manajer (Pasaribu, Topowijono, \& Sulasmiyati, 2016:156).

Komite Audit

Menurut Peraturan Otoritas Jasa Keuangan atau biasa disingkat dengan POJK No. 55/POJK.04/2015 Komite audit adalah komite yang dibentuk oleh Dewan Komisaris serta bertanggung jawab kepada Dewan Komisaris guna membantu Dewan Komisaris dalam pelaksanaan tugas dan fungsinya. Dalam anggota komite audit setidaknya terdiri dari minimal 3 (tiga) orang dan minimal terdapat 1 (satu) orang dari pihak independen atau pihak yang tidak dapat dipengaruhi oleh pihak manapun (Syafitri, Nuzula, \& Nurlaily, 2018:119). 


\section{B. Metode Penelitian}

Penelitian ini merupakan penelitian kuantitatif yang berarti berfokus pada pengolahan statistik, angka, dan percobaan (Hamdi, 2014:5). Data digunakan adalah data sekunder yang berasal dari laporan keuangan perusahaan.

Populasi dari penelitian ini adalah seluruh perusahaan manufaktur yang terdaftar di Bursa Efek Indonesia (BEI) pada periode 2013 - 2017. Pengambilan sampel dalam penelitian ini menggunakan teknik purposive sampling dimana terdapat beberapa kriteria tertentu dalam pengambilan sampel. Kriteria tersebut adalah sebagai berikut:

1. Perusahaaan Manufaktur yang terdaftar di BEI secara berturut-turut pada periode 2013-2017.

2. Perusahaan yang menerbitkan laporan keuangan secara berturut-turut pada periode $2013-2017$.

3. Perusahaan memperoleh laba secara berturut-turut selama periode 2013-2017.

4. Perusahaan yang tutup buku pada tanggal 31 Desember.

\section{Operasionalisasi Variabel}

Kebijakan Dividen

Dalam penelitian ini kebijakan dividen menggunakan pengukuram sebagai berikut (Sartono, 2010:491):

$$
D P R=\frac{\text { Dividend per share }}{\text { Earning per share }}
$$

Keterangan:

Dividend per share $=$ dividen dibagi jumlah saham beredar

Earning per share = laba dibagi jumlah saham beredar

Kebijakan Utang

Menurut Sartono (2010:121) kebijakan utang dapat diukur dengan Debt to Equity Ratio (DER):

$$
D E R=\frac{\text { Total utang }}{\text { Jumlah modal sendiri }}
$$

Profitabilitas

Dalam penelitian ini profitabilitas menggunakan pengukuran sebagai berikut (Syamsuddin, 2011:74):

$$
R O E=\frac{\text { Laba bersih setelah pajak }}{\text { modal sendiri }} \times 100 \%
$$


Kepemilikan Manajerial

Dalam penelitian ini kepemilikan manajerial menggunakan pengukuran sebagai berikut (Puspaningrum, 2017:6):

$$
K M=\frac{\text { Jumlah saham manajemen }}{\text { jumlah saham yang beredar }}
$$

Komite Audit

Menurut Sarafina \& Saifi (2017) komite audit dapat diukur dengan:

$K A=\frac{\text { Komisaris Independen dalam komite audit }}{\text { Jumlah Komite Audit }}$

Nilai Perusahaan

Dalam penelitian ini, nilai perusahaan menggunakan pengukuran sebagai berikut:

$$
\operatorname{Tobin}^{\prime} s Q=\frac{\text { MVE }+\mathrm{D}}{\mathrm{TA}}
$$

Keterangan:

MVE = Market Value of Equity atau Nilai Pasar Perusahaan diperoleh dari jumlah saham yang beredar dikali dengan harga saham akhir tahun

$\mathrm{D}=$ Debt atau Total Utang perusahaan

TA = Total Assets perusahaan

\section{Hasil dan Pembahasan}

Populasi dalam penelitian ini adalah perusahaan manufaktur yang terdaftar di BEI selama periode 2013-2017. Jumlah populasi penelitian ini adalah sebanyak 167 perusahaan. Berdasarkan kriteria yang telah ditentukan, maka diperoleh perusahaan manufaktur yang tidak terdaftar berturut-turut dari 2013-2017 sebanyak 33 perusahaan, perusahaan yang mengalami kerugian sebanyak 62 perusahaan dan perusahaan yang tutup buku selain 31 desember sebanyak 2 perusahaan. Jadi total sampel yang diperoleh adalah sebanyak 70 perusahaan sehingga total data penelitian adalah 350 perusahaan. Uji yang dilakukan adalah Uji Asumsi Klasik dan Uji Hipotesis.

Uji asumsi klasik digunakan untuk memastikan apakah data yang digunakan dalam penelitian tidak terjadi penyimpangan dan dinyatakan layak. Uji asumsi klasik terdiri dari Uji Normalitas, Uji Multikolinearitas, Uji Autokorelasi, dan Uji Heteroskedastisitas. Sedangkan Uji hipotesis terdiri dari Analisis Regresi Sederhana, Uji F dan Uji T. Data dalam penelitian ini ditransformasi kedalam bentuk logaritma natural (LN) agar lolos dalam uji asumsi klasik. 


\section{A. Analisis Statistik Deskriptif}

\begin{tabular}{lr|r|r|r|r}
\multicolumn{6}{c}{ Tabel 1 Statistik Deskriptif } \\
\hline \multicolumn{7}{c}{ Descriptive Statistics } \\
\hline Tobin's Q & 350 & .30 & 23.29 & 2.2742 & Minimum \\
\hline DPR & 350 & .00 & 1866.45 & 40.6466 & 106.51881 \\
\hline DER & 350 & .04 & 7.44 & .9187 & .87996 \\
\hline ROE & 350 & .01 & 143.53 & 16.3731 & 21.34786 \\
\hline KM & 350 & .00 & .62 & .0383 & .09650 \\
\hline KA & 350 & .00 & .67 & .3458 & .09632 \\
\hline Valid N (listwise) & 350 & & & & \\
\hline Sumberm: Data Sekunder yang diolah & & &
\end{tabular}

Dari tabel 1, dapat dilihat bahwa rata-rata DPR 40.646, DER 0.918, ROE 16.373, KM 0.0383, KA 0.3458. Sedangkan nilai minimum dan maksimum DPR 0.00 dan 1866.45, DER 0.04 dan 7.44, ROE 0.01 dan 143.53, KM 0.00 dan 0.62, dan KA 0.00 dan 0.67.

\section{B. Uji Normalitas}

Gambar 2 Uji Normalitas

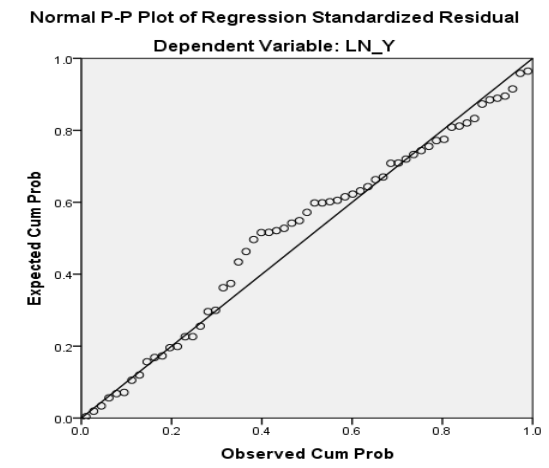

Dari gambar 2 menunjukkan penyebaran titik berada disekitar garis diagonal dan membentuk garis lurus mengikuti garis diagonal, maka dari gambar 2 dapat disimpulkan bahwa data penelitian berdistribusi normal.

\section{Uji Multikolinearitas}

Tabel 2 Uji Multikolinearitas

\begin{tabular}{rlrc}
\hline & & \multicolumn{2}{c}{ Collinearity } \\
& & Statistics \\
& & 0.937 & 1.067 \\
Model & (Constant) & 0.792 & 1.263 \\
1 & Kebijakan Dividen & 0.943 & 1.061 \\
& Kebijakan Utang & 0.718 & 1.392 \\
& Profitabilitas & 0.928 & 1.077 \\
\hline
\end{tabular}

Tabel 2 menunjukkan data pada penelitian ini berupa kebijakan dividen (X1), kebijakan utang (X2), profitabilitas (X3), kepemilikan manajerial (X4), dan komite audit (X5) memiliki nilai tolerance lebih besar dari 0.1 dan memiliki nilai Variance Inflation Factor (VIF) kurang dari 10 maka dapat disimpulkan bahwa data dalam penelitian ini tidak menunjukkan adanya multikolinearitas. 


\section{Uji Autokorelasi}

\section{Tabel 3 Uji Autokorelasi}

\begin{tabular}{ll}
\hline Nilai Durbin-Watson & Keterangan \\
\hline 2.047 & Tidak terjadi autokorelasi \\
\hline
\end{tabular}

Pada tabel Durbin-Watson, dengan signifikansi 5\% serta jumlah data 350 dan $\mathrm{k}$ (jumlah variabel independen) sebanyak 5nilai dU adalah 1,847 dan nilai 4-dU sebesar 2.152. Karena nilai Durbin-Watson sebesar 2.047 lebih besar dibanding dengan nilai dU dan lebih kecil dibanding dengan nilai 4-dU maka dapat disimpulkan bahwa tidak terjadi autokorelasi positif maupun negatif.

\section{E. Uji Heteroskedastisitas}

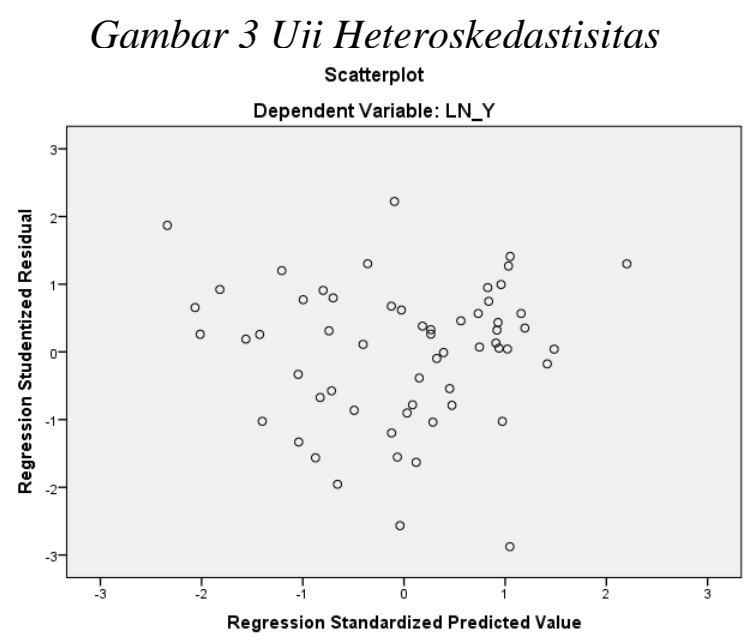

Gambar 3 menunjukkan penyebaran titik memperlihatkan bahwa titik menyebar secara acak dan tidak membentuk pola tertentu, selain itu penyebaran titik juga berada di atas dan di bawah angka 0 maka dapat disimpulkan bahwa data pada penelitian tidak terjadi heteroskedastisitas.

\begin{tabular}{|c|c|c|c|c|}
\hline \multicolumn{5}{|c|}{ Tabel 4 Uji Chi Square } \\
\hline & & & Adjusted & Std. Error of the \\
\hline Model & $\mathrm{R}$ & R Square & R Square & Estimate \\
\hline 1 & 0.513 & 0.264 & 0.194 & 1.78 \\
\hline
\end{tabular}

Nilai R Square dalam tabel 4 menunjukkan angka sebesar 0.264. Nilai $\mathrm{c}^{2}$ hitung diperoleh dari n x R Square, jadi nilai $\mathrm{c}^{2}$ hitung adalah 350 x $0.264=92.4$. Dengan nilai signifikansi 0.05 dan Df (n-1) adalah 349 dapat diperoleh nilai $\mathrm{c}^{2}$ tabel sebesar 393.563. oleh karena nilai $c^{2}$ hitung yang lebih kecil dari nilai $\mathrm{c}^{2}$ tabel $(92.4<$ 393.563) maka dapat disimpulkan bahwa tidak terjadi heteroskedastisitas. 


\section{F. Uji Hipotesis}

1. Uji F

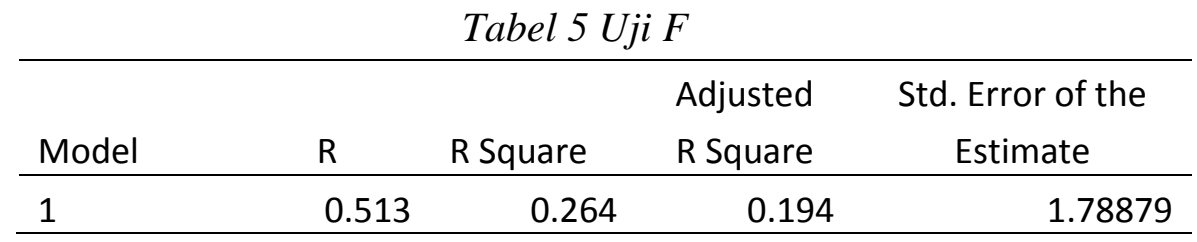

Pada tabel 5, nilai signifikansi menunjukkan nilai 0.005 lebih kecil dari 0.05. maka dapat disimpulkan bahwa kebijakan dividen, kebijakan utang, profitabilitas, kepemilikan manajerial, dan komite audit secara bersama-sama berpengaruh terhadap nilai perusahaan.

\section{Uji T}

\begin{tabular}{|c|c|c|c|c|c|c|}
\hline \multicolumn{7}{|c|}{ Tabel 6 Uji T } \\
\hline \multirow[b]{2}{*}{ Model } & & \multicolumn{2}{|c|}{$\begin{array}{c}\text { Unstandardized } \\
\text { Coefficients }\end{array}$} & $\begin{array}{l}\text { Standardized } \\
\text { Coefficients }\end{array}$ & \multirow[b]{2}{*}{$\mathrm{t}$} & \multirow[b]{2}{*}{ Sig. } \\
\hline & & $B$ & Std. Error & Beta & & \\
\hline 1 & (Constant) & -2.019 & 4.769 & & -0.423 & 0.674 \\
\hline & Kebijakan Dividen & -0.504 & 0.305 & -0.201 & -1.653 & 0.104 \\
\hline & Kebijakan Utang & -0.429 & 0.285 & -0.200 & -1.507 & 0.138 \\
\hline & Profitabilitas & 0.821 & 0.256 & 0.389 & 3.205 & 0.002 \\
\hline & Kepemilikan Manajerial & 0.054 & 0.182 & 0.041 & 0.297 & 0.768 \\
\hline & Komite Audit & 0.185 & 3.963 & 0.006 & 0.047 & 0.963 \\
\hline
\end{tabular}

Kebijakan dividen yang memiliki nilai signifikansi lebih dari 0.05 dan nilai $\mathrm{t}$ hitung sebesar -1.653 lebih kecil dari nilai t tabel yaitu 1.966. Dari kedua hasil tersebut dapat disimpulkan jika kebijakan dividen tidak berpengaruh terhadap nilai perusahaan. Hasil uji $\mathrm{T}$ tersebut sesuai dengan teori yang dikemukakan oleh Modigliani-Miller (MM) yaitu teori Dividen Tidak Relevan (Dividend Irrelevance Theory). Teori tersebut menyatakan pembayaran dividen tidak mempengaruhi kemakmuran para pemegang saham (Nainggolan dan Listiadi, 2014:871). Hasil penelitian ini sejalan dengan penelitian yang dilakukan oleh Kartini \& Apriwenni (2017), dan Assyaari, Pratomo, \& Yudhowati (2018) yang menyatakan bahwa kebijakan dividen tidak berpengaruh terhadap nilai perusahaan.

Kesimpulan dari hasil tabel 6 adalah kebijakan utang tidak berpengaruh terhadap nilai perusahaan. Hasil penelitian ini sejalan dengan hasil penelitian yang telah dilakukan oleh Ayem \& Nugroho (2016) dan Jusriani \& Rahardjo (2013) yang menyatakan bahwa kebijakan utang tidak berpengaruh terhadap nilai perusahaan. Nilai perusahaan yang tinggi atau pun rendah tidak dipengaruhi dengan besar atau kecilnya penggunaan utang pada perusahaan.

Profitabilitas yang diukur dengan ROE memiliki nilai signifikansi kurang dari 0.05 , sedangkan nilai t hitung lebih besar dari nilai t tabel yaitu sebesar 3.205. Nilai koefisien profitabilitas menunjukkan nilai 0.821. Berdasarkan hasil tersebut dapat 
disimpulkan bahwa profitabilitas berpengaruh positif terhadap nilai perusahaan. Hasil penelitian ini sejalan dengan penelitian yang dilakukan oleh Ayem \& Nugroho (2016), Rahmawati, Topowijono, \& Sulasmiyati (2015), dan Hasibuan, AR, \& NP (2016) yang menyatakan profitabilitas berpengaruh positif terhadap nilai perusahaan. Hal ini berarti semakin tinggi profitabilitas perusahaan maka semakin tinggi pula nilai perusahaan.

Kepemilikan manajerial dalam tabel 6 menunjukkan nilat t hitung lebih kecil dari nilai t tabel yaitu sebesar 0.297. Sedangkan nilai signifikansi kepemilikan manajerial lebih dari 0.05. Berdasarkan hasil uji T tersebut maka dapat disimpulkan kepemilikan manajerial tidak berpengaruh terhadap nilai perusahaan. Penelitian ini selaras dengan hasil penelitian yang dilakukan oleh Syafitri, Nuzula, \& Nurlaily (2018) dan Dewi \& Sanica (2017) yang menyatakan besarnya persentase kepemilikan saham pihak manajemen tidak mempengaruhi tinggi rendahnya nilai perusahaan.

Komite audit memiliki nilai t hitung lebih kecil dari nilai t tabel sebesar 0.047. Sedangkan nilai signifikansi menunjukkan nilai yang lebih dari 0.05. Kesimpulan dari hasil di atas adalah komite audit tidak berpengaruh terhadap nilai perusahaan. Hasil penelitian ini selaras dengan penelitian yang dilakukan oleh Rahmawati, Topowijono, \& Sulasmiyati (2015) dan Agustiani (2016) yang menyatakan bahwa komite audit berpengaruh terhadap nilai perusahaan. Komite audit hanya bertugas sebagai pengawas perusahaan oleh karena itu kehadiran komite audit tidak diperhatikan oleh para calon investor.

\section{Analisis Regresi Berganda}

Dari tabel 6 diperoleh persamaan regresi berganda sebagai berikut: $\mathrm{Y}=-2.019+(-0.504) \mathrm{X} 1+(-0.429) \mathrm{X} 2+0.821 \mathrm{X} 3+0.054 \mathrm{X} 4+0.185 \mathrm{X} 5$

\section{Kesimpulan}

Simpulan dari hasil penelitian ini adalah:

1. Kebijakan Dividen tidak berpengaruh terhadap nilai perusahaan manufaktur yang terdaftar di BEI pada periode 2013-2017.

2. Kebijakan utang tidak berpengaruh terhadap nilai perusahaan.

3. Profitabilitas berpengaruh positif terhadap nilai perusahaan.

4. Kepemilikan Manajerial tidak berpengaruh terhadap nilai perusahaan.

5. Komite audit tidak berpengaruh terhadap nilai perusahaan.

6. Secara simultan, kebijakan dividen, kebijakan utang, profitabilitas, kepemilikan manjerial dan komite audit berpengaruh secara bersama-sama terhadap nilai perusahaan. 


\subsection{Keterbatasan}

Penelitian ini memiliki keterbatasan yaitu:

1. Penelitian ini hanya berfokus pada perusahaan manufaktur sehingga tidak dapat mewakili keseluruhan perusahaan yang ada.

2. Periode penelitian ini yang hanya 5 tahun dari 2013-2017.

3. Penelitian ini hanya mengandalkan laporan keuangan pada perusahaan manufaktur sehingga informasi yang di dapatkan hanya berasal dari laporan keuangan perusahaan

Saran bagi peneliti selanjutnya, sebagai berikut:

1. Pengambilan variabel independen. Karena dalam penelitian ini hanya profitabilitas saja yang berpengaruh terhadap nilai perusahaan sedangkan variabel independen lainnya tidak berpengaruh terhadap nilai perusahaan.

2. Pengukuran nilai perusahaan selain Tobin's Q, seperti PBV atau PER..

3. Menggunakan sampel perusahaan dari sektor lain, selain perusahaan Manufaktur. 


\section{Referensi}

Ahalik. (2017). Akuntansi untuk Perusahaan Jasa, Dagang, dan Manufaktur Berbasis IFRS. Jakarta: IAI.

Assyaari, M. F., Pratomo, D., \& Yudowati, S. P. (2018). Pengaruh Kebijakan Pendanaan, Kebijakan Dividen, dan Profitabilitas terhadap Nilai Perusahaan. e-Proceeding of Management, 5 No. 1, 628-637.

Ayem, S., \& Nugroho, R. (2016). Pengaruh Profitabilitas, Struktur Modal, Kebijakan DIviden, dan Keputusan Investasi terhadap Nilai Perusahaan. Jurnal Akuntansi, Vol.4 No.1, 31-39.

Dhani, I. P., \& Utama, A. G. (2017). Pengaruh Pertumbuhan Perusahaan, Struktur Modal, dan Profitabilitas terhadap Nilai Perusahaan. Jurnal Riset Akuntansi dan Bisnis Airlangga, 2 No. 1, 135-148.

Ghozali, I. (2018). Aplikasi Analisis Multivariate dengan Program IBM SPSS 25 (9 ed.). Semarang: Badan Penerbit Universitas Diponnegoro.

Godfrey, J. M. (2010). Accounting Theory (7th ed.). Australia: John Wiley \& Sons Australia, Ltd.

Hamdi, A. S., \& Bahruddin, E. (2014). Metode Penelitian Kuantitatif Aplikasi dalam Pendidikan. Yogyakarta: Deepublish.

Jensen, M. C., \& Meckling, W. H. (1976). Theory of the firm: Managerial behavior, agency costs and ownership structure. Journal of Financial Economics, 3(4), 305-360.

Kartini, R. D., \& Apriwenni, P. (2017). Dampak Perencanaan Pajak, Kebijakan Hutang, dan Kebijakan Dividen terhadap Nilai Perusahaan. Jurnal Akuntansi Perpajakan, Vol. 6 No. 1, 47-67.

Mulyawan, S. (2015). Manajemen Keuangan. Bandung: Pustaka Setia.

Muryati, N. N., \& Suardikha, I. M. (2014). Pengaruh Corporate Governance pada Nilai Perusahaan dengan Kebijakan Dividen sebagai variabel moderasi. E-Jurnal Akuntansi Universitas Udayana, 411-429.

Nainggolan, S. D., \& Listiadi, A. (2014). Pengaruh Kebijakan Utang terhadao Nilai Perusahaan dengan Kebijakan Dividen sebagai variabel moderasi. Jurnal Ilmu Manajemen, Vol. 2 No. 3, 868-879.

Pasaribu, M. Y., Topowijono, \& Sulasmiyati, S. (2016). Pengaruh Struktur Modal, Struktur Kepemilikan, dan Profitabilitas terhadap Nilai Perusahaan pada Perusahaan Sektor Industri Dasar dan Kimia yang terdaftar di BEI tahun 2011-2014. Jurnal Administrasi Bisnis, Vol. 35 No. 1, 154-164.

Prasetyorini, B. F. (2013). Pengaruh Ukuran Perusahaan, Leverage, Price Earning Ratio dan Profitabilitas terhadap Nilai Perusahaan. Jurnal Ilmu Manajemen, Vol. 1 No. 1, 183196.

Puspaningrum, Y. (2017). Pengaruh Corporate Social Responsibility (CSR) dan Kepemilikan Manajerial Terhadap Nilai Perusahaan dengan Profitabilitas dan Ukuran Perusahaan sebagai Variabel Moderating. Jurnal Profita, Edisi 2, 1-14. 
Rahmawati, A. D., Topowijono, \& Sulasmiyati, S. (2015). Pengaruh Ukuran Perusahaan, Profitabilitas, Struktur Modal, dan Keputusan Investasi terhadap Nilai Perusahaan. Jurnal Administrasi Bisnis (JAB), Vol. 23 No. 2, 1-7.

Sarafina, S., \& Saifi, M. (2017). Pengaruh Good Corporate Governance terhadap Kinerja Keuangan dan Nilai Perusahaan. Jurnal Administrasi Bisnis (JAB), 50 No. 2, 108-117.

Sartono, A. (2010). Manajemen Keuangan Teori dan Aplikasi. Yogyakarta: BPFE.

Sunyoto, D. (2013). Analisis Laporan Keuangan untuk Bisnis (Teori dan Kasus). Yogyakarta: CAPS.

Syafitri, T., Nuzula, N. F., \& Nurlaily, F. (2018). Pengaruh Good Corporate Governance (GCG) terhadap Nilai Perusahaan. Jurnal Administrasi Bisnis, 118-126.

Syamsuddin, L. (2011). Manajemen Keuangan Perusahaan (Edisi Kesebelas ed.). Jakarta: Grafindo.

Tambunan, M. C., Saifi, M., \& Hidayat, R. R. (2017). Pengaruh Good Corporate Governance Terhadap Nilai Perusahaan. Jurnal Administrasi Bisnis (JAB)|, 53 No. 1, 49-57.

CNN Indonesia. (2019). “Grab Resmi Umumkan Status Decacorn”. [Online] Diakses pada tanggal 2 maret 2019 dari https://www.cnnindonesia.com/teknologi/20190228092233$\underline{185-373332 / \text { grab-resmi-umumkan-status-decacorn }}$ 